\title{
AT\&T's Strategic Response to Competition: Why Not Preempt Entry?
}

\author{
JoAN NiX AND David Gabel
}

The idea that a monopolist would adopt a pricing strategy to deter entry is found in a wide body of research. We explore why the monopolist in the American telephone industry, AT\&T, did not pursue such a strategy when its initial patents expired.

W illiam Baumol, John Panzar, and Robert Willig; Paul Milgrom and John Roberts; and other theoreticians have pointed out that potential competition is a disciplinary force that affects the pricing decisions of incumbent firms. They have assumed in the development of their models that firms, motivated by the goal of profit maximization, are attentive to the threat of competition and choose pricing strategies to deter entry. ${ }^{1}$ In this article we argue that considering the firm as a profit maximizing agent is only a starting point for explaining its actual conduct. The beliefs of a firm's managers regarding appropriate strategies for meeting competition are also shaped and influenced by the company's history.

At the end of the nineteenth century, the dominant firm in the American telephone industry, the American Telephone and Telegraph Company (AT\&T) did not adopt an entry-deterring price when its initial patents expired. Although committed to maximizing their company's profits over the long run, AT\&T's management believed that control over the industry could be maintained by developing its long-distance network and through patent litigation against its competitors. The evidence we develop shows that their reliance on these strategies to dominate the market-rather than a pricing strategy to deter entry-was shaped by practices and perceptions established during their early managerial careers, both before and after coming to AT\&T.

\section{CONSUMERS' PREFERENCES FOR FLAT-RATE SERVICE}

The years 1879 to 1893 were a prosperous period for AT\&T. The patents issued to Alexander Graham Bell ensured that no other com-

The Journal of Economic History, Vol. 53, No. 2 (June 1993). (c) The Economic History Association. All rights reserved. ISSN 0022-0507.

Joan Nix is Assistant Professor of Economics and David Gabel is Associate Professor of Economics, Queens College, City University of New York, Flushing, NY 11367.

We gratefully acknowledge the helpful comments of Elizabeth Hoffman, Richard Vietor, Peter Temin, David Weiman, Tim Brennan, Michael Edelstein, Robert Loube, and Michael Einhorn.

'See, for example, Baumol, Panzer, and Willig, Contestable Markets; Milgrom and Roberts, "Limit Pricing"; Bain, Industrial Organization; and Modigliani, "New Developments." 
pany could provide telephone service, and the strong demand for the new communications technology provided stockholders with a return that was well in excess of the market rate. During this era AT\&T experimented with two pricing structures, flat-rate and local measured service (LMS). With flat-rate service, customers paid a uniform charge regardless of the intensity of local usage. With LMS they paid a fixed fee for access, but their charges increased with the amount of usage.

AT\&T found pricing under local measured service to be the more profitable method in large cities. ${ }^{2}$ At the turn of the century switching was handled by an operator, which made the marginal cost of usage high, especially in comparison with today's automatic switching environment. ${ }^{3}$ The high marginal cost of usage made LMS a prudent pricing method for rationing scarce switching facilities. Moreover, AT\&T's management believed that LMS was a sound method for developing the market. The two-part rate structure lowered the price of joining the network, and AT\&T officials hoped that this would attract additional customers. ${ }^{4}$ At the same time, they believed telephony to be an increasing cost industry. Because the market was growing, AT\&T wanted a pricing strategy that would bring in additional revenue as the cost per customer increased. ${ }^{5}$

When Alexander Graham Bell's patents expired in 1893, AT\&T was faced with the entry of competitors into its market. The newcomers, known collectively as the Independents, appeared first in small cities and towns in the Midwest, but quickly spread out across the nation and into larger cities. The Independents chose to compete with AT\&T by employing a different pricing strategy, selling local service on a flat-rate basis.

Customers exhibited a strong preference for flat-rate pricing. ${ }^{6}$ This preference was dramatically illustrated by the reaction of customers in Rochester, New York, to the introduction of LMS. In November 1886 AT\&T announced that measured service would replace flat-rate service. The subscribers opposed the rate change and, with few exceptions,

\footnotetext{
${ }^{2}$ Bell did not offer measured service in small cities. According to one of AT\&T's leading rate design specialists, U. N. Bethell, measured service was not implemented in small cities because the market was served by one central office. The cost of an interoffice call was considerably higher than a message that originated and terminated on the same switch. One of the primary objectives of measured service pricing was a reduction of the incidence of interoffice calls. American Telephone and Telegraph Corporate Archive (hereafter AT\&TCA), U. N. Bell, "Respecting Rate Plan for Manhattan," Dec. 19, 1898, box 12, "Telephone Rates-Basis."

${ }^{3}$ Compare Wenders, "Two Views," with AT\&TCA, W. S. Ford, "Memorandum: Concerning Certain Peculiar Features of Telephone Exchange Service," Sept. 10, 1901, "Telephone RatesBasis-1880-1908," box 12.

${ }^{4}$ U.S. Department of Commerce, Telephone and Telegraphs, pp. 53-4, 59; and American Telephone and Telegraph Company, 1901 Annual Report, p. 7.

s AT\&TCA, Hall to Hudson, "Long Distance Service-Basis of Rates-1891-1892," Jan. 6, 1892 , box 1291.

${ }^{6}$ AT\&TCA, Thayer to Durant, Feb. 24, 1909, and Pickernell to Thayer, June 2, 1909, "Missouri," box 4.
} 
discontinued service. For a period of 18 months Rochester was essentially without telephone service. In May 1888 AT\&T recanted and committed itself to sell local service on a flat-rate basis until its patents expired in $1893 .^{7}$ In other cities, things did not reach the point of a customer strike, but there were clear signs that customers preferred flat-rate service. ${ }^{8}$

There are a number of factors that explain why customers preferred flat-rate service. Suppose that over the course of a year a customer would monitor her usage and conclude that it was below the network's average. Suppose, she also observed some month-to-month fluctuations in her calling patterns; during some periods her usage may have been below that of average users, while at other times her usage may have exceeded this norm. Based on the assumption of a preference for risk aversion, some customers might have chosen the certainty of flat-rate service despite the potential cost savings of LMS. ${ }^{9}$

Customers may also have favored flat-rate service because of the cost of monitoring usage. Customers who wanted to keep track of how much they were spending would have to keep records of how many calls they had placed. Keeping such records would have been costly, and could also have been seen as a nuisance.

Another reason consumers might have preferred flat-rate service was that it was simpler to understand than a two-part tariff. AT\&T's vice-president, E. J. Hall, conjectured that although customers could understand paying a flat fee for unlimited use of the local network, or no connection charge and a usage charge for each call, they were confused by the combination of paying an entry and usage fee.

The claim that [a two-part tariff] is easy for the customer to understand, and would therefore be popular, is not justified by history nor will it stand logical analysis. No compound proposition [i.e. two-part tariff] can be as easily understood as can either one of the simple ones from which it is composed. ${ }^{10}$

Customer dissatisfaction with local measured service created entrepreneurial opportunities, and flat-rate service became a crucial component of the Independent's strategy. For example, the Wisconsin market, with the exception of Milwaukee, was split between the Independents and AT\&T. AT\&T had a monopoly in Milwaukee and sold service on a measured-service basis. " In 1905 the Wisconsin Independents re-

\footnotetext{
${ }^{7}$ MacMeal, The Story, pp. 110-11.

${ }^{8}$ See, for example, Milwaukee Journal; Milwaukee Sentinel; Milwaukee Daily News, Nov. 4, 1895; and AT\&TCA, Jackson to French, Oct. 29, 1895, box 1298.

${ }^{9}$ Kahn, Economics of Regulation, vol. 1, p. 192; and Roby, "History and Development," p. 10.

${ }^{10}$ AT\&TCA, Hall to Hudson, Dec. 10, 1898, "New York City-Rates-Changes in Basis1898-1899," box 1287.

The idea that the rationality of individuals is affected by computational limitations is consistent with the concept of bounded rationality. See, for example, Simon, "Behavior Model"; and March, "Bounded Rationality."

"Gabel, "Evolution of a Market," chap. 9.
} 
quested that the Milwaukee City Council grant a franchise to an independent firm, the Milwaukee Independent Telephone Company. Appearing before the Council in support of the petition, the President of the Wisconsin Independent Telephone Association questioned the proposed requirement that service be sold on a measured basis.

We do not believe [an entrant who must price on a measured basis] would be successful in any city where the competition is strong. . . . There is no doubt but that a measured service is a mighty good thing for a [monopolist]. There is more money in it. . . I do not think any of us could compete with the Bell company for a month using measured service. ${ }^{12}$

Although it is clear why the pricing strategy of the Independents took into account the desire of many customers for flat-rate service, it is striking that AT\&T failed to preempt the Independents by offering flat-rate service in the first place. One way to conceive of AT\&T's situation is that, confronted with potential rivals, it faced two courses of action. One was to disregard customers' sentiments and maximize short-term profits with LMS. The drawback to that approach was that customer dissatisfaction created entrepreneurial opportunities and therefore encouraged entry. Alternatively, AT\&T could have confronted customer dissatisfaction and restricted entrepreneurial opportunities for the Independents by selling service on a flat-rate basis. It is not clear that such a strategy would have resulted in a loss of profits. During the patent era, AT\&T had charged high prices and had not introduced service in rural areas or in small cities and towns. By the end of this period, the company had installed only 270,000 telephones. Thirteen years after the beginning of the competitive era, the number of subscribers served by AT\&T and the Independents had grown to $6,000,000$. Gerald Brock has argued that this rapid growth suggests that during the monopoly period AT\&T had underestimated the price elasticity of demand, and, therefore, deterring entry by reducing and realigning prices would not have necessarily issued in a sacrifice of short-term profits. ${ }^{13}$

There appear to have been sound reasons why AT\&T, as a profitmaximizing agent, should have adopted a pricing strategy to preempt entry. The firm's patents, which had served as a formidable barrier-toentry, were set to expire in 1893 and 1894, and the Independents' market strategy was based on addressing the accumulated grievances of its customers. Public hostility toward AT\&T's rates was evident in newspaper editorials that denounced the Bell system. ${ }^{14}$ Some officials within AT\&T's operating companies recognized the extent of customer dissatisfaction and sought to generate public goodwill through rate changes. For example, Charles Haskins, President of AT\&T's subsidiary Wis-

\footnotetext{
12 Telephony, p. 28; and Milwaukee Daily News, Dec. 21, 1905.

13 Brock, Telecommunications Industry, p. 122.

14 Wisconsin State Journal; and Western Electrician.
} 
consin Telephone, asserted that if rates were not lowered, a competitor would be "greeted gladly." is

The incentive for AT\&T to address customer dissatisfaction by adopting flat-rate service was particularly strong in the Midwest. There was strong antimonopoly sentiment in this region, and it was likely that potential entrants would be granted franchises and be well received by consumers. The Independents achieved their greatest success in Indiana, Ohio, and Illinois. From 1894 to 1913 AT\&T operated its exchanges in these states at a loss. But it also invested approximately $\$ 30$ million in the same states during that period, despite the prospect that its operating company in the area would "have no earning capacity for a long-time." 16

AT\&T's failure to adopt flat-rate service prior to the entry of competitors allowed the Independents to obtain early successes, and it was only after it had lost a significant share of the market that it changed its pricing policy. ${ }^{17}$ Once the switch to flat-rate service was made, however, competitive market forces made it unprofitable for AT\&T to return to LMS. W. S. Allen, who was responsible for monitoring the Independents for the President of AT\&T, wrote his superior in 1903 that "so long as competition exists in the shape in which it does in [Ohio, Indiana, and Illinois,] we will be obliged to pay little attention to measured service..."18 Figure 1 shows that in large cities, the markets where AT\&T was most interested in using LMS, the likelihood of its serving its customers on a measured basis was affected by the level of competition. As the Independent's market share in a city increased, the proportion of AT\&T's customers served with LMS declined. ${ }^{19}$

\section{UNDERSTANDING AT\&T'S RESPONSE}

At the start of the twentieth century telephony was a relatively new industry, and it was not at all obvious whom it would serve. ${ }^{20}$ Thus both the uses to which a telephone network could be put and how to sell the

15 AT\&TCA, Haskins to Vail, Feb. 14, 1884, box 1141.

${ }^{16}$ AT\&TCA, Minutes of Director's Meeting, Central Union Telephone Company, Jan. 17, 1900, at 39; American Telephone and Telegraph, "Brief and Argument"; and AT\&TCA, Fish to Sabin, Dec. 24, 1902 (quote only), vol. 2, Private Presidential Letter Books.

${ }^{17}$ AT\&TCA, Thayer to Durant, Feb. 24, 1909, and Pickernell to Thayer, June 2, 1909, "Missouri," box 4; and Brock, Telecommunications Industry, pp. 111-12.

${ }^{18}$ AT\&TCA, Allen to Fish, Feb. 11, 1903, box 1333. See also AT\&TCA, Fish to Wallace, Feb. 18, 1903, Presidential Letter Books, vol. 26.

19 The historical evidence contradicts John Wenders's modeling of pricing of local service in a competitive market. Wenders ("Two Views," p. 342) concluded that flat-rate pricing is "unsustainable" because "where competition is present. . . . the individuals for whom it is not beneficial will turn to competitors, and this will destroy flat-rate pricing." We believe that his model does not capture the actual evolution of the market, because it does not take into account risk aversion, transaction costs, or bounded rationality.

${ }^{20}$ Aronson, "Bell's Electrical Toy," p. 19. 


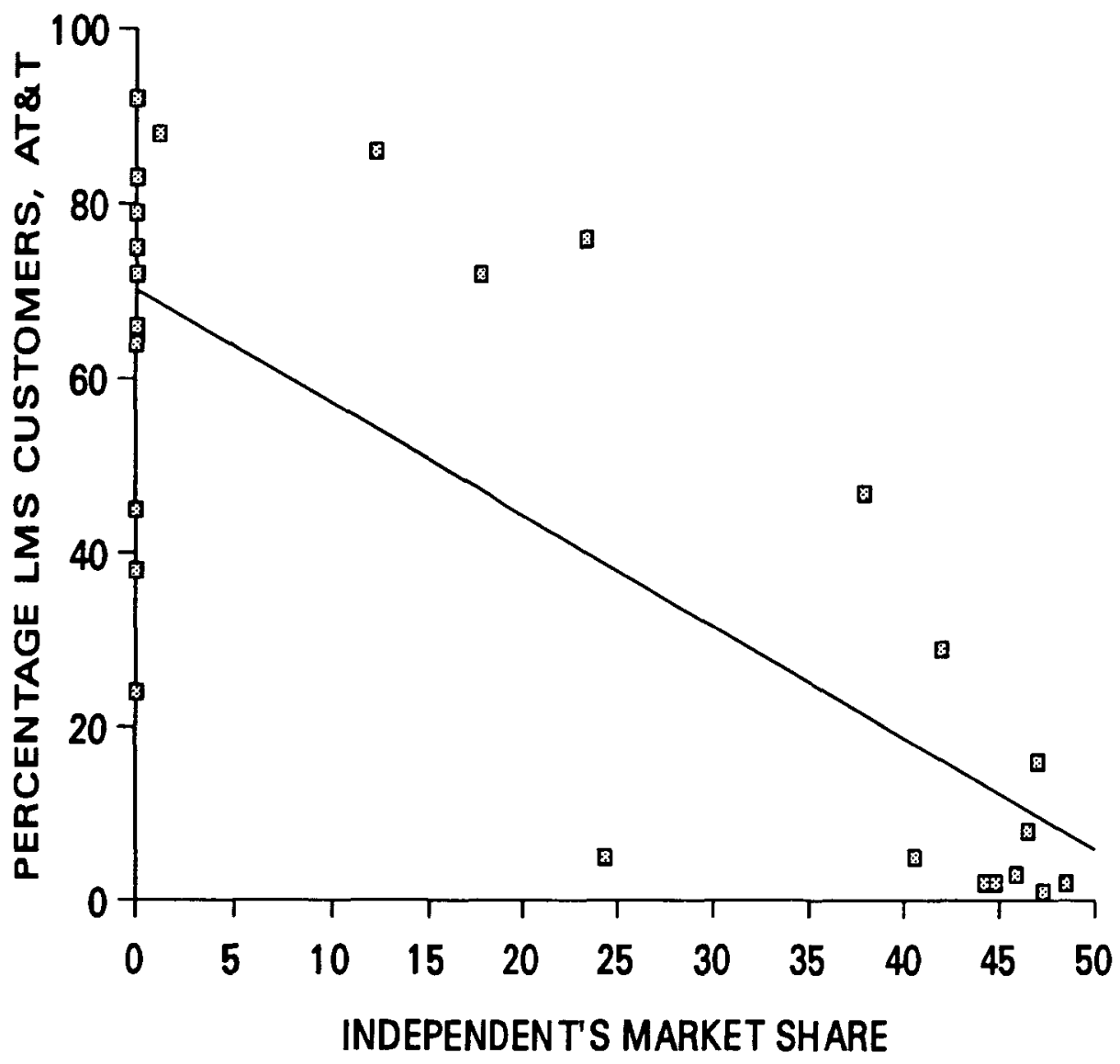

FIGURE 1

RELATIONSHIP BETWEEN MARKET AND PRICING STRUCTURE IN CITIES WITH OVER 125,000 CITIZENS, 1912

Note: The fitted line on the figure is based on the regression

$$
L M S=\underset{(11.50)}{70.08}-\frac{1.28}{(-6.18)} \cdot I N D E P S H A R E
$$

( $t$ statistics are shown in parentheses; $N$ equals $25, R^{2}$ equals .6076)

where $L M S$ equals the percentage of AT\&T's customers served with $L M S$ and INDEPSHARE equals the percentage of the city market share held by the independent.

Sources: AT\&TCA, DuBois to Vail, August 20, 1909, box 1375; and American Telephone and Telegraph Company. Relation Between Bell Telephones.

service were open to debate. The nature of the debate was influenced by the past experiences of AT\&T and its managers.

Many of the key officials in AT\&T had learned their marketing skills while working for telegraph companies. The telegraph was used almost exclusively for business and not social purposes. Their previous managerial experience, therefore, made the idea of using a communications 
network for socializing anathema to many officials of the Bell System. ${ }^{21}$ Management's perspective on the appropriate use of the network is reflected in a notice that explained to the firm's patrons why flat-rate service would be replaced with measured service.

The unlimited use of the telephone leads to a vast amount of unnecessary occupation of the wires, and to much borrowing of telephones by parties who are not subscribers. Thus the telephone system is so encumbered with calls which are unnecessary, and largely illegitimate, that the service is greatly impaired, and subscribers, to whom prompt connection is essential, become dissatisfied. ${ }^{22}$

LMS, with its nonzero price for usage, discouraged the use of the telephone for social communication. For AT\&T to have recognized the preemptive value of moving away from local measured service, a fundamental change in the way the firm perceived its product would have been required.

AT\&T also favored LMS because they believed that it would increase network membership. The president of AT\&T, Frederick Fish, believed that customers valued access and that charging a low fee for network membership would maximize the number of subscribers. According to Fish, the number of users was an important determinant of the value of telephony to individual subscribers. ${ }^{23}$ His desire to maximize network connections led the firm to adopt a pricing structure in which prices to residential customers were actually set below the marginal cost of service in order to encourage subscription. These losses were made up through increased charges to business customers. ${ }^{24}$

Fish's belief that value was created largely through the number of customers connected to the network, rather than the number of calls, made it difficult for him to recognize the utility of flat-rate service as a pricing policy to preempt entry. But there were other possible ways to conceptualize the process of network formation. AT\&T officials could have conceived the value of network participation as based largely on the number of connections, rather than the number of members connected to the network. ${ }^{25}$ Maximum use of the network for a given number of subscribers would have been achieved under flat-rate service. A zero-usage price would have encouraged consumers to use the telephone for both business and social purposes. But this conception would have clashed with the past experiences of AT\&T's officials in

\footnotetext{
${ }^{21}$ Fischer, "Touch Someone," pp. 56-60; American Telephone and Telegraph Company, 1901 Annual Report, p. 7.

${ }^{22}$ AT\&TCA, "Notice to Public," July 1880, box 12, "Telephone Rates-Basis."

${ }^{23}$ American Telephone and Telegraph Company, 1901 Annual Report.

${ }^{24}$ AT\&TCA, Fish to Wallace, Nov. 26, 1904, PLB, vol. 36. See also AT\&TCA, W. S. Ford, "Memorandum: Concerning Certain Peculiar Features of Telephone Exchange Service," Sept. 10, 1901, "Telephone Rates-Basis-1880-1908," box 12.

${ }^{25}$ Communications theory emphasizes this view of network membership. Mulgan, Communications and Control, pp. 5-6, 21.
} 
telegraphy which had led them to view telephony as a primarily a service for the business community.

Fish's idea of creating value through maximizing membership led him to focus on the importance of long-distance telephony. As the number of connected network nodes increased, so would the quantity of customers that could be reached, and, in Fish's view, the increase in the number of customers would raise the value of obtaining service from AT\&T. Five years before the expiration of Bell's patents, this theme had been developed by E. J. Hall. Hall argued that toll calling provided important external benefits to the local exchanges that were most likely to face competition: ". . . the continued success of the local exchanges will be largely in proportion to their ability to connect satisfactorily with our [toll] lines."26 Because of AT\&T's first mover advantage in longdistance telephony, its top leaders did not think that a new pricing strategy for local service was needed in order to deter entry.

AT\&T also thought that its operations would be protected by a patent on an improved transmitter granted in 1891. That patent was soon challenged by the federal government on the grounds that its processing had been improperly delayed by the company. AT\&T won the court case, but its success was short lived. In 1895, the company filed a suit against an Independent manufacturer for infringement of the patent. In this case, the court again sustained the patent, but interpreted it so narrowly that it became "worthless as a device for prolonging the Bell monopoly." 27 Despite this major loss in the courts, AT\&T continued its efforts to hinder the development of the Independents through patent infringement suits. That strategy was pursued by the Company until 1907, when its new President, Theodore Vail, convinced the board of directors that competition could not be controlled through patent litigation. ${ }^{28}$

AT\&T's management found patent litigation an attractive strategy for deterring competition in large part because of the success the firm had had with this approach prior to 1893. Its delay in modifying its approach to the market in the face of potential competition should not be taken as evidence that it was, in any fundamental way, a noninnovative firm. In the 1890s AT\&T did, in fact, pursue an important, and forward-looking strategy in its recognition and development of long distance telephony. Yet, in some respects, AT\&T's innovativeness in this area also inhibited its response to competition. By focusing on the development of longdistance telephony, the firm failed to recognize the need to design a pricing strategy for local service that would preempt entry. ${ }^{29}$

${ }^{26}$ AT\&TCA, Hall to Hudson Jan. 21, 1888, box 1011.

27 Federal Communications Commission, Investigation, pp. 133-34.

${ }^{28}$ MacMeal, The Story, p. 129; and Simpson, "Monopoly Building Techniques," pp. 18-19.

${ }^{29}$ Garnet, Telephone Enterprise, pp. 44-45, 92; and AT\&TCA, Hudson to Payne, May 17, 1895, vol. 6, Presidential Letter Books. 
Although we have argued that AT\&T's profits would have been higher than the observed values if the firm had preempted entry by selling local service on a flat-rate basis, society as a whole would likely have been worse off. The rapid growth of the telephone market during the competitive period suggests that rivalry forced the firms to actively solicit customers. ${ }^{30}$ Because of competition, firms engaged in efforts to attract customers that were not characteristic of either the monopoly period or the period after AT\&T regained control of the market. As a leading official of AT\&T noted, competition had forced his firm to "go after the business." 31

\section{CONCLUSION}

The commitment of AT\&T's officials to LMS made it difficult for them to recognize the value of flat-rate service as a preemptive move. The strength of their commitment is not difficult to understand when it is placed in historical context. The decisions of AT\&T's managers were shaped by the business practices that they had learned while working for telegraph companies, as well as during the monopoly period of telephony. Their perception of the primary determinants of network value also influenced the selection of corporate strategies. Only when AT\&T faced increasing competition from the Independents did the firm shift strategy and adopt flat-rate service.

In recent years some large firms have demonstrated a similar unwillingness to shift strategies until faced with strong rivals. For example, only after IBM lost significant market share to rivals in the information processing market, did the firm exhibit a willingness to change the focus of its operations from mainframe to personal computers and work stations.

The experience of AT\&T at the turn of the century, and many firms today, suggests that a firm's business strategies are much less malleable than current theories of profit maximization would predict. Neoclassical economists often subsume expectations and preferences under the assumption of profit or utility maximization. Our explanation of AT\&T's response to the threat of competition illustrates that the behavior of managers also depends on their beliefs about the characteristics of their product and the nature of their market. Most importantly, such beliefs cannot be understood without reference to history. Reconciling the predictions of neoclassical models with the behavioral diversity of firms will be much easier when economists recognize that behavior cannot be predicted from economic rationality alone. The conceptual framework that a firm employs to determine profit-maximizing behavior is shaped and conditioned by history.

${ }^{30}$ Bureau of the Census, Historical Statistics, vol. 2, p. 783.

${ }^{31}$ AT\&TCA, Allen to Fish, May 16, 1906, Allen Letter Books. 


\section{REFERENCES}

American Telephone and Telegraph, "Brief and Argument for Appellant," in Read v. Central Union Telephone Company, Appellate Court of Illinois, First District, Gen. No. 23664, Mar. 1918, at 2.

American Telephone and Telegraph Company, 1901 Annual Report.

American Telephone and Telegraph Company, Relation Between Bell Telephones and Population in Cities of Over 50,000 Population (New York, 1913).

American Telephone and Telegraph Corporate Archive (AT\&TCA), Warren, NJ.

Aronson, Sidney, "Bell's Electrical Toy: What's the Use? The Sociology of Early Telephone Usage," in Ithiel de Sola Pool, ed., The Social Impact of the Telephone (Cambridge, MA, 1977), pp. 15-39.

Bain, Joe, Industrial Organization (New York, 1956).

Baumol, William, John Panzar, and Robert Willig, Contestable Markets and the Theory of Industry Structure (New York, 1982).

Brock, Gerald W., The Telecommunications Industry: The Dynamics of Market Structure (Cambridge, MA, 1981).

Federal Communications Commission, Investigation of the Telephone Industry in the United States (Washington, DC, 1939).

Fischer, Claude S., "Touch Someone: The Telephone Industry Discovers Sociability, 1876-1940," Technology and Culture, 29 (Jan. 1988), pp. 32-61.

Gabel, David, "The Evolution of a Market: The Emergence of Regulation in the Telephone Industry of Wisconsin, 1893-1917"' (Ph.D. diss., University of Wisconsin, Madison, 1987).

Garnet, Robert W., The Telephone Enterprise: The Evolution of the Bell System's Horizontal Structure, 1876-1909 (Baltimore, 1985).

Kahn, Alfred, The Economics of Regulation: Principles and Institutions, 2 vols. (New York, 1971).

MacMeal, Harry, The Story of Independent Telephony (Chicago, 1934).

March, James G., "Bounded Rationality, Ambiguity, and the Engineering of Choice," Bell Journal of Economics, 9 (Autumn 1978).

March, James G., and Zur Shapira, "Behavioral Decision Theory and Organizational Decision Theory," in Gerardo Ungson and Daniel Braunstein, eds., Decision Making: An Interdisciplinary Inquiry (Boston, 1982).

Milgrom, Paul, and John Roberts, "Limit Pricing and Entry under Incomplete Information," Econometrica, 50 (Mar. 1982), pp. 443-59.

Milwaukee Daily News, Nov. 4, 1895; and Dec. 21, 1905.

Milwaukee Journal, Oct. 27, 1895.

Milwaukee Sentinel, Oct. 27, 1895.

Modigliani, Franco, "New Developments on the Oligopoly Front," Journal of Political Economy, 66 (June 1958), pp. 215-32.

Mulgan, G. J., Communications and Control (New York, 1991).

Roby, William, "History and Development of Plant and Rates of the Telephone Industry" (Paper presented at the June 1947 Conference of State Utilities Commission Engineers).

Simon, Herbert, "A Behavioral Model of Rational Choice," Quarterly Journal of Economics, 69 (1955), pp. 99-118.

Simpson, Floyd, "Monopoly Building Techniques, Costs, Prices and Market Structure in the Telephone Industry" (Ph.D. diss., University of Minnesota, 1944).

Telephony, 11 (Jan. 1906).

U.S. Department of Commerce, Bureau of the Census, Telephone and Telegraphs: 1902 (Washington, DC, 1906). 
U.S. Department of Commerce, Bureau of the Census, Historical Statistics of the United States: Colonial Times to 1970, vol. 2 (Washington, DC, 1975).

Western Electrician, Mar. 16 and Mar. 30, 1895.

Wisconsin State Journal, Dec. 31, 1895.

Wenders, John T., "Two Views of Applied Welfare Analysis: The Case of Local Telephone Service Pricing," Southern Economic Journal, 57 (Oct. 1990), pp. $340-48$. 